\title{
Vegetation connectivity increases ant activity and potential for ant-provided biocontrol services in a tropical agroforest
}

\author{
Estelí Jimenez-Soto $^{1 *}$ (i) | Jonathan R. Morris ${ }^{2 *}$ | Deborah K. Letourneau ${ }^{1}$ | \\ Stacy M. Philpott ${ }^{1}$
}

${ }^{1}$ Environmental Studies Department, University of California, Santa Cruz, Santa Cruz, California

${ }^{2}$ School for Environment and Sustainability, University of Michigan, Ann Arbor, Michigan

Correspondence

Estelí Jimenez-Sot, Environmental Studies Department, University of California, Santa Cruz, Santa Cruz, CA.

Email: maesjime@ucsc.edu

Funding information

Consejo Nacional de Ciencia y Tecnología; UC-MEXUS; UCSC Heller Agroecology

Graduate Student Research Grant

\begin{abstract}
In natural and managed systems, connections between trees are important structural resources for arboreal ant communities with ecosystem-level effects. However, ongoing agricultural intensification in agroforestry systems, which reduces shade trees and connectivity between trees and crop plants, may hinder ant recruitment rates to resources and pest control services provided by ants. We examined whether increasing connectivity between coffee plants and shade trees in coffee plantations increases ant activity and enhances biological control of the coffee berry borer, the most devastating insect pest of coffee. Further, we examined whether artificial connections buffer against the loss of vegetation connectivity in coffee plants located at larger distances from the nesting tree. We used string to connect Inga micheliana shade trees containing Azteca sericeasur ant nests to coffee plants to compare ant activity before and after placement of the strings, and measured borer removal by ants on coffee plants with and without strings. Ant activity significantly increased after the addition of strings on connected plants, but not on control plants. Borer removal by ants was also three times higher on connected plants after string placement. Greater distance from the nesting tree negatively influenced ant activity on control coffee plants, but not on connected plants, suggesting that connections between coffee plants and nest trees could potentially compensate for the negative effects that larger distances pose on ant activity. Our study shows that favoring connectivity at the local scale, by artificially adding connections, promotes ant activity and may increase pest removal in agroecosystems.
\end{abstract}

Abstract in Spanish is available with online material.

KEYWORDS

ant foraging, Azteca ants, biological control, coffee berry borer, foraging behavior, vegetation connectivity

\section{1 | INTRODUCTION}

Habitat complexity is critical for the functioning of ecological communities in both terrestrial and aquatic systems. Processes such as

*These authors contributed equally to this work and share first authorship. resource foraging, colonization, and species interactions often depend on the level of heterogeneity in the configuration of physical elements in a habitat (Lassau and Hochuli, 2004; Lassau, Hochuli, Cassis, \& Reid, 2005). Vegetation connectivity and structure are important components of habitat complexity and can influence species interactions and community patterns at local scales. In aquatic 
systems, more complex habitats made up of macrophytes support communities that are more diverse and abundant, and allow for greater food capture than systems without vegetation (Crowder, Mccollum, \& Martin, 1998; Warfe \& Barmuta, 2004). In terrestrial systems, vegetation structure-such as the biomass of foliage and the variety of plant architectures-generally influences species composition, and increases species richness and abundance of numerous taxa (Adams, Schnitzer, \& Yanoviak, 2017; Andersen, 1986; Halaj, Ross, \& Moldenke, 1998; Langellotto \& Denno, 2004). Additionally, vegetation structure can influence mobility and foraging success of vertebrates and invertebrates (Arroyo-Rodríguez, Asensio, Dunn, Cristóbal-Azkarate, \& Gonzalez-Zamora, 2015; Verdeny-Vilalta, Aluja, \& Casas, 2015; Wells, Pfeiffer, Lakim, \& Linsenmair, 2004; Yanoviak \& Schnitzer, 2013).

In tropical ecosystems, ants are among the most abundant and biodiverse of taxonomic groups (Longino, Coddington, \& Colwell, 2002) and are considered important predators, herbivores, and seed dispersers (Camargo, Martins, Feitosa, \& Christianini, 2016; Davidson, Cook, Snelling, \& Chua, 2003; Floren, Biun, \& Linsenmair, 2002). Ants are cursorial central-place foragers-organisms that forage from a central place to which they return with food to feed with the colony (Mayo \& Benabib, 2009). Therefore, foraging and discovery of food resources is strongly constrained by the need to construct and follow trails along vegetation (Farji-Brener et al., 2007; Gordon, 2012; Yanoviak, Silveri, Stark, Van Stan, \& Leiva, 2017). This is particularly relevant for ants using the arboreal stratum as their primary foraging space (Apple \& Feener, 2001; Hashimoto, Morimoto, Widodo, \& Mohamed, 2006; Powell et al., 2011; Tanaka, Yamane, \& Itioka, 2010). For instance, the availability of vegetation connections (e.g., branches, leaves, vines, lianas, bark, and moss) can maximize ants' foraging efficiency, locomotion, and velocity (Clay, Bauer, Solis, \& Yanoviak, 2010; Fewell, 1988; Torres-Contreras \& Vasquez, 2004), as well as contribute to changes in community composition and species richness (Adams et al., 2017; Lassau et al., 2005; Yanoviak \& Schnitzer, 2013). The availability of such resources can ultimately lead to differences in resource utilization by ant communities (Cogni, Freitas, \& Oliveira, 2003; Ozaki, Takashima, \& Suko, 2000).

In tropical agricultural systems, especially agroforests, ants play important ecological roles (Clausen, 1940; Leston, 1973; Offenberg, 2015), and management practices can strongly influence ant behavior and their potential for providing biological pest control services (Abdulla, Rwegasira, Jensen, Mwatawala, \& Offenberg, 2016; Armbrecht \& Gallego, 2007; Teodoro, Sousa-Souto, Klein, \& Tscharntke, 2010). Indeed, one of the oldest known records of the use of ants for pest control dates to 304 A.D in citrus plantations in China. In these systems, artificial connections made of bamboo were used by farmers to facilitate foraging by the Weaver Ant (Oecophila smaragdina) to suppress damaging phytophagous insects. (Huang \& Yang, 1987). In that same study, Huang and Yang (1987) report anecdotal evidence that suggests equal yields in orchards that use chemicals vs. orchards that use ant bridges to control for pests. Similarly, Peng and Christian (2014), report lower levels of fruit damage in cashew with the presence of weaver ants. However, as vegetation complexity declines in agroecosystems, tree density and diversity may also decrease (Bos et al., 2007; Moguel \& Toledo, 1999), as well as the possibility to generate connections between the arboreal vegetation, which might impact arthropod populations (Bos et al., 2007). The lack of connectivity between trees in managed systems can have a significant impact on the mobility of worker ants and their ability to control resources. This impact may be particularly marked at greater distances from the nest, where ant dominance may be lower (Ennis, 2010). This in turn may influence the ecosystem services provided by ants, particularly the suppression of pest outbreaks (Ozaki et al., 2000).

Shaded coffee plantations, which maintain high levels of shade and structural complexity (Moguel \& Toledo, 1999), can sustain complex networks of organisms, which can result in biological pest control (Vandermeer, Perfecto, \& Philpott, 2010). In coffee systems, ants are a functionally diverse and abundant group of ground and arboreal-nesting arthropods and are considered important biological control agents (Morris, Jimenez-Soto, Philpott, \& Perfecto, 2018; Philpott \& Armbrecht, 2006). Ants are predators of the most devastating coffee pest, the coffee berry borer (CBB; Hypothenemus hampei), a beetle that drills cavities in coffee berries and severely damages the seed (Barrera, 2002; Camilo, Olivares, \& Jimenez, 2003). Several species of arboreal ants, with nests attached to or inside tree trunks, branches, or twigs, control adult and immature stages of this pest either through direct predation or deterrence (Gonthier, Ennis, Philpott, Vandermeer, \& Perfecto, 2013; Larsen \& Philpott, 2010; Morris \& Perfecto, 2016). Ants of the genus Azteca are numerically dominant in shaded coffee plantations. These ants forage intensively on coffee plants (as a result of an ant-hemipteran mutualism), and deter CBB adults by removing them from the coffee plant, therefore lowering fruit damage (Jiménez-Soto, CruzRodríguez, Vandermeer, Perfecto, Nuñez, Philpott, Ballinas, 2002, Vandermeer, \& Perfecto, 2013). In shaded coffee plantations, Azteca sericeasur ants nest on shade trees (Vandermeer et al., 2010) and access adjacent coffee plants through the leaf litter or available pathways, such as fallen branches, vines, and other vegetation (personal observation), matching the description by Longino (2007) for this species in forest habitats. In more intensively managed coffee systems, with fewer and more distant nesting trees, connectivity may be sparse or absent and artificial connections might buffer against this loss. Vegetation structure and arboreal characteristics in coffee plantations are likely to be important factors influencing ant foraging behavior and nesting in arboreal ants (De La Mora, Murnen, \& Philpott, 2013; Urrutia-Escobar \& Armbrecht, 2013). However, the influence of vegetation connectivity on the foraging of this dominant arboreal ant and its effect on pest removal in coffee plantations has not yet been studied.

Previous work has documented the importance of arboreal connections for ants and biological control in agricultural systems. For example, various studies and farmers' manuals suggest that connecting nests to adjacent trees using bamboo strips enables weaver ants to colonize new trees, which increases ants' efficiency in removing pests, including the pentatomid insect Tesserarotoma papillosa (Huang 
\& Yang, 1987; Peng \& Christian, 2014; Van Mele, Cuc, Seguni, Camara, \& Offenberg, 2009; Van Mele \& Vayssières, 2007). However, there is little evidence about the effect of increasing arboreal connectivity on biological control using experimental data. We report an experiment testing the influence of adding connections between shade trees and coffee plants and its effects on CBB removal on coffee plants. To our knowledge, this is the first study providing experimental data on the effect of adding connectivity on ant activity and pest removal in coffee agroecosystems. Specifically, we tested one hypothesis: Connectivity affects $C B B$ removal in this system by increasing recruitment rates of A. sericeasur ants to prey items; we predicted that (a) A. sericeasur ants use artificial connections between nesting trees and coffee plants; (b) plants with connectivity have higher ant activity than isolated plants; (c) plants with connections have grater removal rates of CBB by A. sericeasur ants; and (d) A. sericeasur activity and CBB removal rates by A. sericeasur ants decrease with increased distance from A. sericeasur nests.

\section{2 | METHODS}

\subsection{Study site}

We conducted the study in a 300 ha shaded coffee plantation in the Soconusco region of Chiapas, Mexico. The coffee plantation is located at 1,100 m a.s.l. in the Sierra Madre de Chiapas Mountains. The natural vegetation types are high and mid-elevation perennial forest and the climate is semitropical with rainfall typically occurring between May and October (4,000-5,000 mm annually). The coffee plantation can be characterized as a commercial polyculture, where coffee plants grow under the canopy of shade of trees, mostly in the genus Inga (Fabaceae: Mimosoideae; Moguel \& Toledo, 1999), providing an average canopy cover of 75\% (Pak, Iverson, Ennis, Gonthier, \& Vandermeer, 2015).

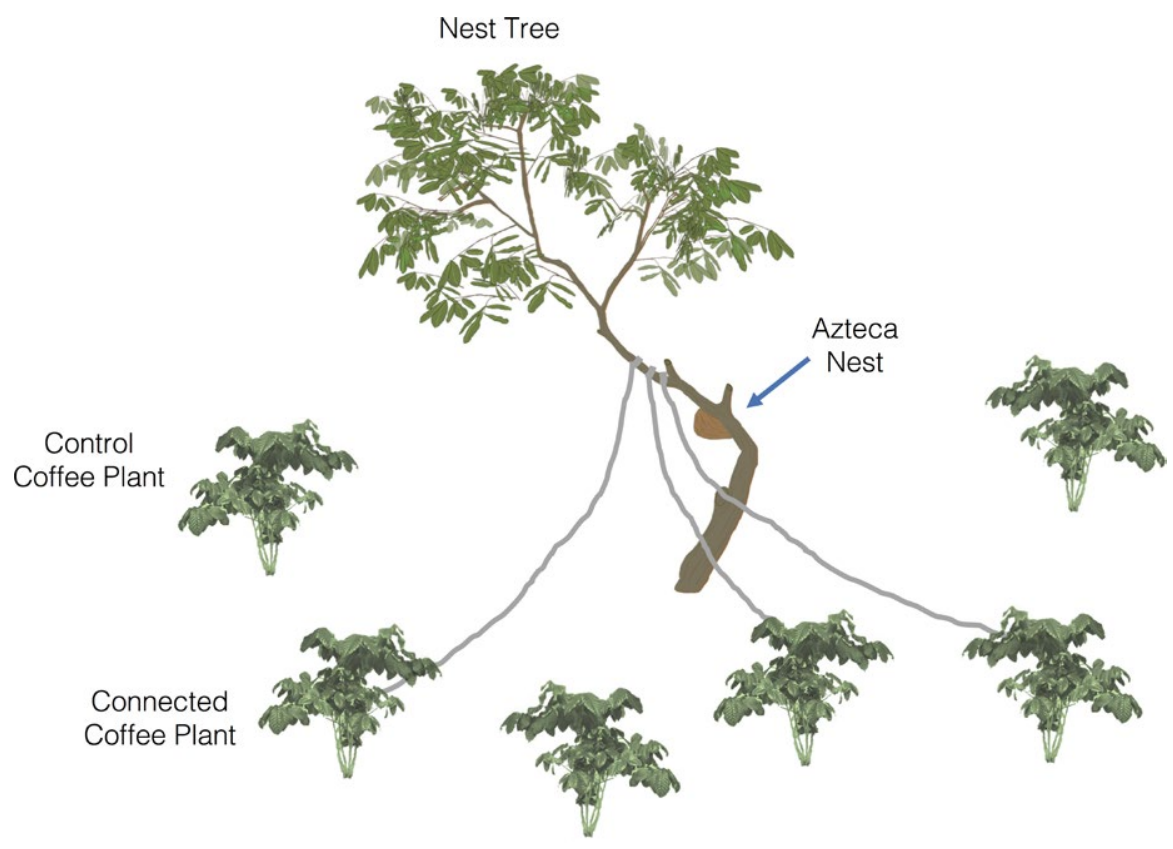

\section{2 | Field experiment}

Within the farm, we haphazardly selected 20 non-overlapping sites located at least $10 \mathrm{~m}$ away from each other with one Inga micheliana tree containing an A. sericeasur carton nest on the tree trunk (referred to as the nesting tree). Azteca sericeasur is a polydomous, arboreal ant species (Longino, 2007), which occurs in $~ 13 \%$ of trees at our study site (unpublished data), and forages on coffee plants (Vandermeer et al., 2010). Trees were selected only if ant nests were noticeably active. In each site, we quantified ant activity on the nest tree as the number of ants crossing a single point on the main trunk during $1 \mathrm{~min}$. This methodology has been used in previous studies to measure overall ant activity of a nest (Liere and Larsen, 2010; Perfecto \& Vandermeer, 2006). We then selected the six coffee plants nearest to the nesting tree, making sure they were not directly touching each other or the tree by removing branches and vines (Figure 1). We then randomly assigned three of the coffee plants at each site to a connection treatment and three as controls without connections, then measured ant activity on the plants by counting the number of ants passing a point on the central trunk for $1 \mathrm{~min}$. We connected treatment coffee plants (from the main trunk) to the nesting tree (as near as possible to the A. sericeasur nest) using jute string $(0.95 \mathrm{~cm}$ of thickness; Figure 1$)$. Strings remained in the field for 3 days to allow for ant acclimation to disturbance and for ants to establish new foraging pathways. After 3 days, we returned to the sites and re-measured ant activity on the nesting tree and coffee plants. Observations took place between 10 a.m. and 1 p.m. and were immediately stopped as soon as it started raining, as this drastically decreases ant activity.

To test how connectivity impacts potential biological control provided by ants, we added dead adult CBB onto connected and control coffee plants to directly assess ant removal rates. We collected CBB-infested coffee berries from the field, dissected them,
FIGURE 1 Diagram of experimental setup after the placement of strings 
extracted female adult CBB individuals (only mature females bore into berries), and placed them in the freezer for up to $24 \mathrm{hr}$, after which beetles were dead. Three days after placing strings and after re-assessing ant activity, we placed 10 dead CBB adults on a small piece of white card on each coffee plant near the center of the trunk, left cards for $30 \mathrm{~min}$, and then counted the number of CBB remaining. Cards were balanced on coffee branches and were bent slightly to keep the CBB from falling. Restricting movement of sentinel prey, either by gluing them to observation sites or by freezing them, is a common technique for assessing predator behavior (Armbrecht \& Perfecto, 2003; De la Mora et al. 2015; Jedlicka, Greenberg, \& Letourneau, 2011). We used frozen (dead) sentinel prey to increase the availability and similarity of beetles on cards and to reduce the potential for live prey to escape from the arena. To assess whether CBB removal was due to ant activity, we monitored cards across the plot over a period of $30 \mathrm{~min}$ (we walked around the experiment and observed ant behavior, such as encounter and handling of CBB) and recorded any arthropods present. Only ants were observed on the cards, indicating that these were responsible for removing the CBB. Although we acknowledge that the use of dead prey may alter ant behavior, it is already well established that $A$. sericeasur both antagonizes and predates live CBB in the field, and reduces $C B B$ infestation on plants (Gonthier et al., 2013; Jiménez-Soto et al., 2013; Morris, Vandermeer, \& Perfecto, 2015; Morris et al., 2018). We used dead prey in this experiment to more readily assess ant removal rates and infer that these changes translate to changes in the biocontrol efficiency of this ant on live prey.

Immediately following each experiment, we characterized the vegetation in each site because several different environmental factors are known to influence ant foraging in coffee systems (Nestel $\&$ Dickschen, 1990). We measured the percentage of canopy cover (using a spherical densiometer), coffee plant height, and distance from each coffee plant to the central Inga nest tree.

\section{3 | Data analysis}

\subsection{1 | Ant activity on nest tree}

To test for statistical differences in ant activity on nest trees before and after connecting trees to coffee plants, we fit our data to a generalized linear mixed model (GLMM). We included time (before and after string placement), canopy cover, and their interaction as fixed effects (Table 1a). We also modeled nest tree identity as a random effect. To assess count data (our response variable), we originally fit our model to a Poisson distribution with a log link function. However, to correct for observed over-dispersion, we modified our model to a Poisson-lognormal distribution by adding a per-observation random effect term (Elston, Moss, Boulinier, Arrowsmith, \& Lambin, 2001).

\subsubsection{Ant activity on coffee plants}

To test for statistical differences in ant activity on coffee plants before and after establishing connections, we used a GLMM.
TAB LE 1 Model selection table with Akaike information criterion $(\mathrm{AIC})$ and $\triangle \mathrm{AIC}$ for generalized linear mixed models (GLMMs) of (a) ant activity on nest trees, (b) ant activity on coffee plants, and $(\mathrm{c})$ coffee berry borer (CBB) removal

\begin{tabular}{llll} 
Model & $d f$ & AIC & $\Delta$ AIC \\
\hline (a) Ant activity on nest tree & & & \\
\hline$\sim$ Time*Canopy cover + RE & 6 & 315.72 & 0.00 \\
\hline Time + Canopy cover + RE & 5 & 314.32 & 1.40 \\
\hline Canopy cover + RE & 4 & 313.24 & 2.48 \\
\hline Time + RE & 4 & 312.64 & 3.08 \\
$\sim$ RE & 3 & 311.56 & 4.16 \\
\hline
\end{tabular}

(b) Ant activity on coffee plant

\begin{tabular}{|c|c|c|c|}
\hline $\begin{array}{l}\text { Treatment*Time + Treatme } \\
\text { nt*Distance + Coffee } \\
\text { height + Tree activity + RE }\end{array}$ & 11 & $1,123.46$ & 0.00 \\
\hline $\begin{array}{l}\text { Treatment*Time + Treatmen } \\
\text { t }^{*} \text { Distance }+ \text { Tree } \\
\text { activity + RE }\end{array}$ & 10 & $1,125.87$ & -2.41 \\
\hline $\begin{array}{l}\text { Treatment*Time + Treatmen } \\
\mathrm{t}^{*} \text { Distance }+ \text { Coffee } \\
\text { height }+\mathrm{RE}\end{array}$ & 10 & $1,145.70$ & -22.24 \\
\hline 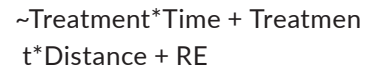 & 9 & $1,148.17$ & -24.71 \\
\hline$\sim \mathrm{RE}$ & 4 & $1,185.37$ & -61.91 \\
\hline \multicolumn{4}{|l|}{ (c) $\mathrm{CBB}$ removal on coffee plant } \\
\hline $\begin{array}{l}\text { Treatment }{ }^{*} \text { Distance }+ \text { Treat } \\
\text { ment*Plant activity }+ \text { Tree } \\
\text { activity + Coffee height }+ \text { RE }\end{array}$ & 10 & 372.26 & 0.00 \\
\hline $\begin{array}{l}\text { Treatment*Distance }+ \text { Treat } \\
\text { ment*Plant activity }+ \text { Tree } \\
\text { activity + RE }\end{array}$ & 9 & 372.98 & -0.72 \\
\hline $\begin{array}{l}\sim \text { Treatment }{ }^{*} \text { Distance }+ \text { Treat } \\
\text { ment }{ }^{*} \text { Plant activity + Coffee } \\
\text { height }+ \text { RE }\end{array}$ & 9 & 409.16 & -36.90 \\
\hline $\begin{array}{l}\sim \text { Treatment }{ }^{*} \text { Distance }+ \text { Treat } \\
\text { ment }{ }^{*} \text { Plant activity }+ \text { RE }\end{array}$ & 8 & 408.18 & -35.92 \\
\hline$\sim R E$ & 3 & 427.46 & -55.20 \\
\hline
\end{tabular}

Note. Models were selected based on AIC comparisons, where a full model of biologically relevant terms was included, along with subsequent models of different covariate combinations and a null intercept-only model of random effects. Best fit was determined via backwards model selection compared to the full model, where the model that resulted in the lowest AIC score was selected. When the best fitted model was not the full model, we selected based on $\triangle \mathrm{AIC}>+2$. RE indicates random effects and asterisks indicate interaction terms. The selected model is shown in bold.

We included time (before and after string placement), treatment (connected vs. control plants), coffee plant distance to nest tree, the interaction between time and treatment, and the interaction between time and distance as fixed effects (Table $1 \mathrm{~b}$ ). We also included coffee plant height and ant activity on nest tree as covariates. Random effects were modeled with plant identity nested within site (nest tree identity) to account for the block design of the experiment (spatial non-independence) and to control for 
variation between our sites. To model count data and to correct for overdispersion, we used a Poisson-lognormal model with a log link function by including a per-observation random effect as described above (Elston et al., 2001).

\subsection{3 | Coffee berry borer removal}

We modeled CBB removal by ants using a GLMM. We included treatment (connected vs. control plants), coffee plant distance to nest tree, ant activity on coffee plants after string placement, the interaction between treatment and distance, and the interaction between treatment and ant activity on plants as fixed effects (Table 1c). We also included ant activity on nest tree and coffee plant height as covariates. Random effects were modeled with plant identity nested within site (nest tree identity) to account for the block design of the experiment (spatial non-independence) and to control for variation between our sites. To model count data in our response variable, we used a Poisson distribution with a log link function.

\subsubsection{Model selection and inference}

We constrained model selection to include biologically pertinent terms for inference and to aid in model interpretation. A full model of these terms was tested, along with subsequent models of different covariate combinations and a null intercept-only model of random effects (Table 1). The best fit model was determined via backwards model selection compared to the full model, where the model that resulted in the lowest AIC was selected, if $\triangle \mathrm{AIC}>+2$ when the best fitted model was not the full model.

Overall significance in models was assessed using Wald type II Chi-squared tests. Statistical differences among treatments were compared by Wald $Z$ tests (Tables 2 and 3 ). In all cases, fixed effect parameters and the variance of random effects were estimated by maximum likelihood with Laplace approximation using the "glmer" function in the "Ime4" package in R (Bates, Maechler, Bolker, \& Walker, 2014, R Development Core Team, 2014). To aid in data interpretation, we removed one coffee plant replicate from our analysis where measured ant activity was more than double that of any other plant measured and may have resulted from an unusually high buildup of scale insects which are tended by $A$. sericeasur on coffee. Additionally, one nest tree replicate was not included in the tree activity analysis because the data were not collected at that site. Finally, coffee plant height and distance to nest tree were centered and scaled to aid model interpretation. All analyses were performed in R (R Development Core Team, 2014).

\section{3 | RESULTS}

We observed $A$. sericeasur ants using artificial connections at all sites (Figure $2 \mathrm{~A}$ ) and on $75 \%$ of all strings placed in the field. Other ant species such as Cephalotes basalis and Pseudomyrmex simplex co-occurred with $A$. sericeasur ants on the strings (Figure $2 B$ ), but not on the cards.
TAB LE 2 Model results for our generalized linear mixed model of ant activity on coffee plants with parameter estimates $( \pm S E)$, Wald Z scores, and $p$-values

\begin{tabular}{|c|c|c|c|}
\hline Parameter & Estimate $( \pm S E)$ & $z$ value & $p(>|z|)$ \\
\hline \multicolumn{4}{|c|}{ Reference: Treatment (control); Time (before) } \\
\hline (Intercept) & $-0.127 \pm 0.277$ & -0.457 & 0.648 \\
\hline Treatment (connected) & $0.174 \pm 0.257$ & 0.676 & 0.499 \\
\hline Time (after) & $0.115 \pm 0.242$ & 0.475 & 0.635 \\
\hline Distance & $-0.472 \pm 0.152$ & -3.102 & 0.002 \\
\hline Tree activity & $0.014 \pm 0.008$ & 1.847 & 0.065 \\
\hline Plant height & $0.233 \pm 0.109$ & 2.132 & 0.033 \\
\hline $\begin{array}{l}\text { Treatment } \\
\text { (connected)*Time (after) }\end{array}$ & $0.950 \pm 0.324$ & 2.930 & 0.003 \\
\hline $\begin{array}{l}\text { Treatment (connected)* } \\
\text { Distance }\end{array}$ & $0.409 \pm 0.200$ & 2.048 & 0.041 \\
\hline \multicolumn{4}{|c|}{ Reference: Treatment (control); Time (after) } \\
\hline (Intercept) & $-0.010 \pm 0.305$ & -0.032 & 0.975 \\
\hline Treatment (connected) & $1.124 \pm 0.249$ & 4.525 & $<0.001$ \\
\hline Time (before) & $-0.116 \pm 0.242$ & -0.479 & 0.632 \\
\hline Distance & $-0.474 \pm 0.152$ & -3.113 & 0.002 \\
\hline Tree activity & $0.014 \pm 0.008$ & 1.840 & 0.066 \\
\hline Plant height & $0.234 \pm 0.109$ & 2.142 & 0.032 \\
\hline $\begin{array}{l}\text { Treatment (connected)* } \\
\text { Time (before) }\end{array}$ & $-0.951 \pm 0.325$ & -2.929 & 0.003 \\
\hline $\begin{array}{l}\text { Treatment } \\
\text { (connected)*Distance }\end{array}$ & $0.411 \pm 0.200$ & 2.056 & 0.040 \\
\hline \multicolumn{4}{|c|}{ Reference: Treatment (connected); Time (before) } \\
\hline (Intercept) & $0.049 \pm 0.272$ & 0.180 & 0.857 \\
\hline Treatment (control) & $-0.175 \pm 0.257$ & -0.679 & 0.497 \\
\hline Time (after) & $1.067 \pm 0.221$ & 4.834 & $<0.001$ \\
\hline Distance & $-0.063 \pm 0.139$ & -0.456 & 0.649 \\
\hline Tree activity & $0.014 \pm 0.008$ & 1.837 & 0.066 \\
\hline Plant height & $0.233 \pm 0.109$ & 2.137 & 0.033 \\
\hline $\begin{array}{l}\text { Treatment (control)*Time } \\
\text { (after) }\end{array}$ & $-0.951 \pm 0.325$ & -2.930 & 0.003 \\
\hline $\begin{array}{l}\text { Treatment (control)* } \\
\text { Distance }\end{array}$ & $-0.411 \pm 0.200$ & -2.058 & 0.040 \\
\hline \multicolumn{4}{|c|}{ Reference: Treatment (connected); Time (after) } \\
\hline (Intercept) & $1.114 \pm 0.278$ & 4.009 & $<0.001$ \\
\hline Treatment (control) & $-1.125 \pm 0.249$ & -4.525 & $<0.001$ \\
\hline Time (before) & $-1.068 \pm 0.221$ & -4.835 & $<0.001$ \\
\hline Distance & $-0.061 \pm 0.139$ & -0.442 & 0.659 \\
\hline Tree activity & $0.014 \pm 0.008$ & 1.842 & 0.065 \\
\hline Plant height & $0.233 \pm 0.109$ & 2.135 & 0.033 \\
\hline $\begin{array}{l}\text { Treatment (control)*Time } \\
\text { (before) }\end{array}$ & $0.952 \pm 0.325$ & 2.932 & 0.003 \\
\hline $\begin{array}{l}\text { Treatment } \\
\text { (control)*Distance }\end{array}$ & $-0.413 \pm 0.200$ & -2.068 & 0.039 \\
\hline
\end{tabular}

Note. Each output group shows the results for each possible set of references for the categorical variables treatment (connected vs. control) and time (before vs. after placement of strings). Asterisks indicate an interaction and significant $(p<0.05)$ model terms are shown in bold. 
TAB LE 3 Model results for our generalized linear mixed model of coffee berry borer removal (CBB) by ants with parameter estimates $( \pm S E)$, Wald $Z$ scores, and $p$-values

\begin{tabular}{|lrrr|}
\hline Parameter & Estimate $( \pm S E)$ & $z$ value & $p(>|z|)$ \\
\hline Reference: Treatment (connected) & & & \\
\hline (Intercept) & $-1.281 \pm 0.605$ & -2.117 & 0.034 \\
\hline Treatment (control) & $-1.481 \pm 0.554$ & -2.673 & 0.008 \\
\hline Distance & $0.018 \pm 0.263$ & 0.067 & 0.947 \\
\hline Plant activity & $0.064 \pm 0.036$ & 1.804 & 0.071 \\
\hline Plant height & $0.397 \pm 0.240$ & 1.658 & 0.097 \\
\hline Tree activity & $0.026 \pm 0.015$ & 1.711 & 0.087 \\
\hline Treatment(control)*Distance & $-0.404 \pm 0.414$ & -0.974 & 0.330 \\
\hline Treatment(control)*Plant & $0.014 \pm 0.047$ & 0.292 & 0.771 \\
\hline activity & & & \\
\hline Reference: Treatment (control) & & & \\
\hline (Intercept) & $-2.742 \pm 0.642$ & -4.272 & $<0.001$ \\
\hline Treatment (connected) & $1.540 \pm 0.553$ & 2.783 & 0.005 \\
\hline Distance & $-0.361 \pm 0.326$ & -1.106 & 0.269 \\
\hline Plant activity & $0.081 \pm 0.035$ & 2.347 & 0.019 \\
\hline Plant height & $0.387 \pm 0.238$ & 1.625 & 0.104 \\
\hline Tree activity & $0.025 \pm 0.014$ & 1.777 & 0.076 \\
\hline Treatment & $0.385 \pm 0.412$ & 0.934 & 0.350 \\
\hline (connected)*Distance & & & \\
\hline Treatment (connected)*Plant & $-0.018 \pm 0.047$ & -0.387 & 0.699 \\
\hline activity & & & \\
\hline
\end{tabular}

Note. The two output groups show the results for both references of the categorical variable treatment (connected vs. control). Asterisks indicate an interaction and significant $(p<0.05)$ model terms are shown in bold.

\section{1 | Ant activity on nest trees}

Although there was an $18.6 \%$ increase in ant activity on nest trees after experimental set up (Figure $3 \mathrm{~A}$ ), including time (before and after string placement) in our model did not improve its explanatory power. Canopy cover also varied from 53\% to $94 \%$ among sites; however, including it as a factor did not improve model fit. The GLMM that best explained ant activity on trees was our null intercept-only model (Table 1a). Thus, we did not further assess statistical significance for our model of ant activity on nest trees.

\subsection{Ant activity on coffee plants}

The model that best predicted ant activity on coffee plants included time (before and after string placement), treatment (connected vs. control plants), coffee plant distance to nest tree, the interaction between treatment and distance, and the interaction between treatment and ant activity on plants as fixed effects (Table 1b). This model also included coffee plant height and ant activity on nest tree as covariates.

Overall, ant activity increased in coffee plants after the placement of strings $\left(\chi^{2}=14.94, p<0.001\right.$, Figure $\left.3 \mathrm{~B}\right)$. However, this effect was only significant in connected coffee plants $(z=4.83$, $p<0.001$, Table 2 ), which increased in activity by $163.4 \%$ after string placement, as opposed to only a $56.4 \%$ increase in control coffee plants ( $z=0.48, p=0.635$, Table 2). The significant interaction between time (before and after string placement) and treatment (connected vs. control) in our model $\left(\chi^{2}=8.58, p=0.003\right.$ ) indicates that there was a significantly greater increase in ant activity on connected plants than on control plants after string placement (Figure 3B).

Distance between coffee plants and nest trees varied from 0.65 to $3.5 \mathrm{~m}$. Overall, ant activity significantly decreased as the distance of coffee plants from nest trees increased $\left(\chi^{2}=5.54, p=0.019\right)$. However, after string placement (Figure 4), this effect was only significant in control plants $(z=-3.11, p=0.002$, Table 2$)$, whereas connected plants had lower decreases in ant activity with distance ( $z=-0.44, p=0.659$, Table 2 ), as indicated by the significant interaction term between treatment and distance in our model $\left(\chi^{2}=4.23\right.$, $p=0.040$ ). Additionally, coffee plant height varied from 0.2 to $3.0 \mathrm{~m}$ and explained some of the variation in plant ant activity $\left(\chi^{2}=4.59\right.$, $p=0.032)$; however, ant activity on the nest tree was not a significant covariate in our model $\left(\chi^{2}=3.39, p=0.066\right)$.

\subsection{Coffee berry borer removal}

The GLMM that best explained CBB removal was our full model, which included treatment (connected vs. control), coffee plant distance to tree, ant activity on coffee plants after string placement, the interaction between treatment and ant activity on plants, and the interaction between treatment and coffee plant distance as fixed effects (Table 1c). This model also included coffee plant height and ant activity on the nest tree as covariates.
FIGURE 2 Azteca sericeasur workers cross from the nesting tree to coffee plants on strings that simulate arboreal connections (a) and co-occur with other ants, such as Cephalotes basalis (b)

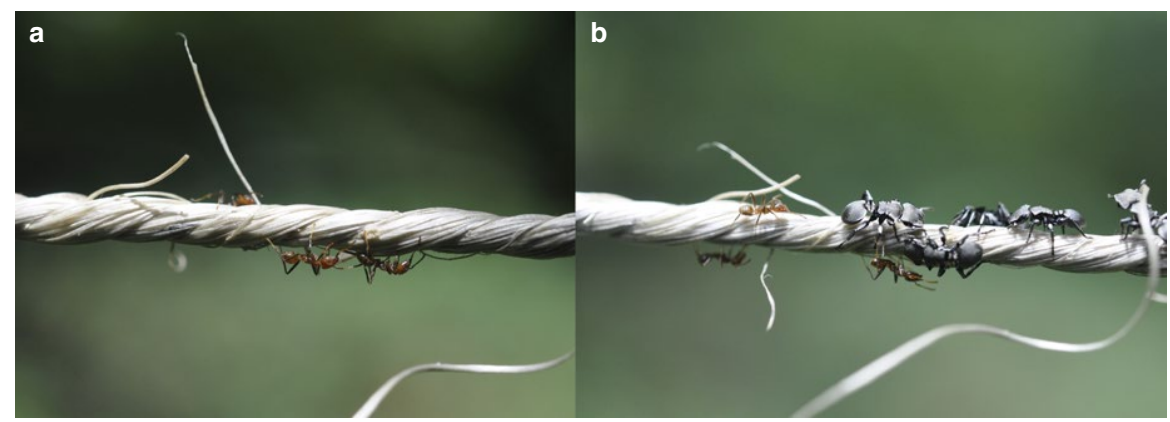



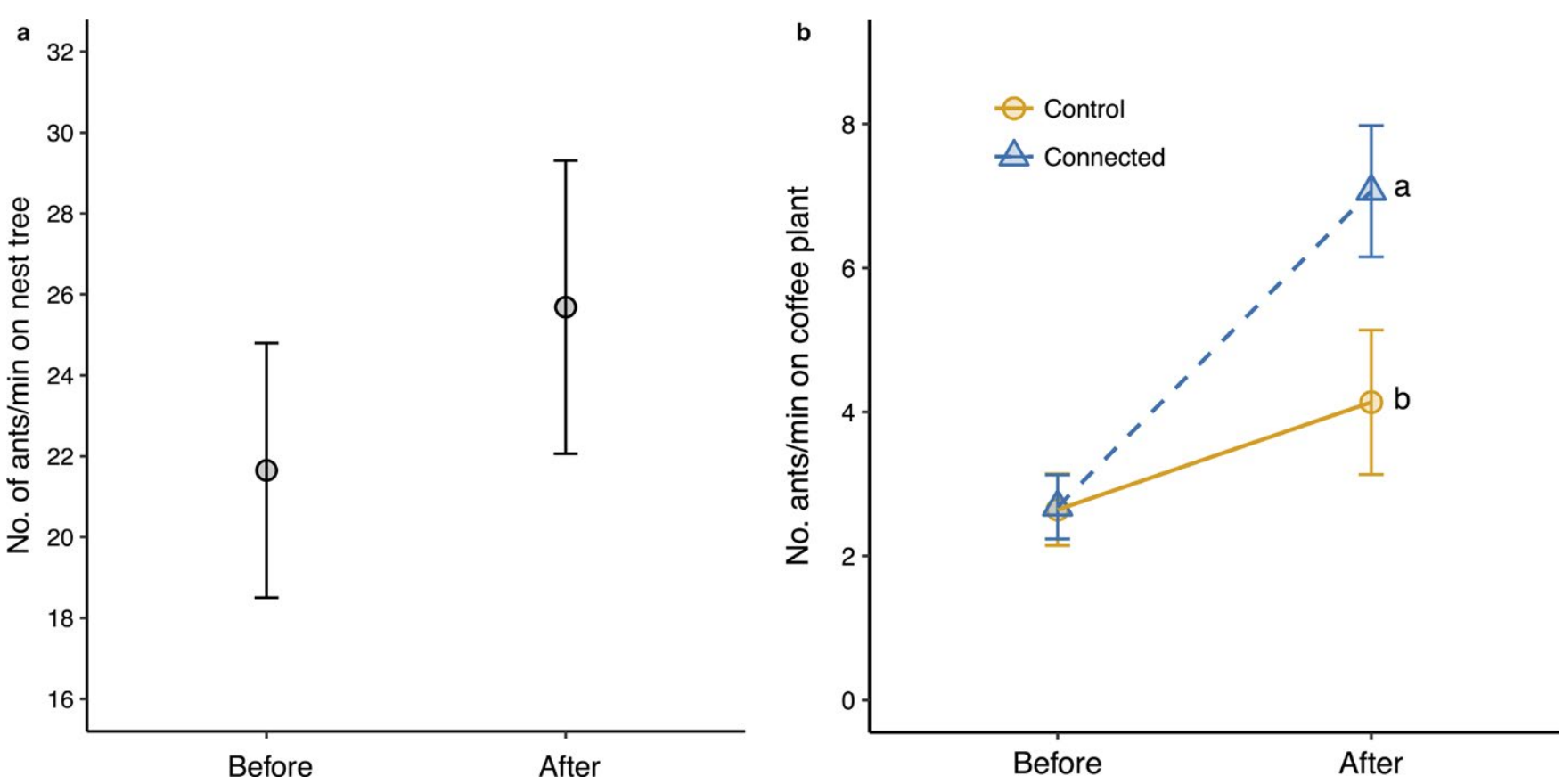

FIGURE 3 Azteca sericeasur activity on nest trees (a) and on coffee plants (b), before and after the placement of strings. In (b), different letters represent a statistically significant interaction $(p<0.05)$ between treatment (control vs. connected) and time (before and after string placement), indicating a greater overall increase in activity on connected plants. Bars $=$ Mean $( \pm S E)$

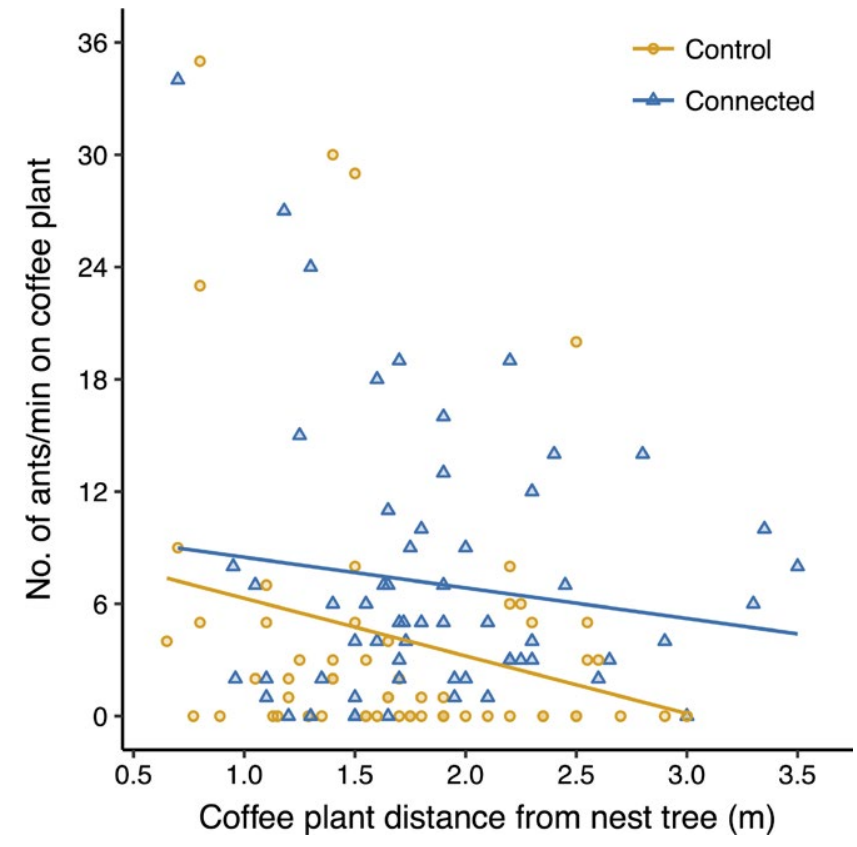

FIGURE 4 Azteca sericeasur activity on coffee plants after the placement of strings as a function of distance from the nest tree. In our GLMM, ant activity significantly declined with increasing distance in control plants $(z=-3.11, p=0.002)$, but not in connected plants $(z=-0.44, p=0.659)$, as indicated by the significant interaction between treatment and distance $\left(\chi^{2}=4.23\right.$, $p=0.040$ )

Coffee berry borer removal was nearly three times higher on connected coffee plants than on control coffee plants $\left(\chi^{2}=9.82\right.$, $p=0.002$, Figure 5). Overall, the effect of coffee plant ant activity on $\mathrm{CBB}$ removal was significant $\left(\chi^{2}=7.91, p=0.005\right.$, Supporting Information Figure S1); however, this effect was significant on control plants $(z=2.35, p=0.019$, Table 3$)$, but only marginally significant on connected plants in our model $(z=1.80, p=0.071$, Table 3). Despite this, the interaction between treatment (control vs. connected) and ant activity on coffee plants was not significant $\left(\chi^{2}=0.15, p=0.699\right)$, indicating that ant activity on coffee plants and treatment independently drive CBB removal. CBB removal rate was not significantly affected by distance to the nesting tree $\left(\chi^{2}=0.37\right.$, $p=0.545$ ). Additionally, neither coffee plant height nor ant activity on nest tree was significant covariates in our model (Table 3). Although we chose the full model based on the lowest AIC value as explained in our methods, it should be noted that the second best model (with a $\triangle \mathrm{AIC}$ of -0.72 ) does not include coffee height, which suggests that it may not be a very important variable for determining the removal rate of $\mathrm{CBB}$.

\section{4 | DISCUSSION}

Our experiment demonstrates that the addition of string to connect shade trees and coffee plants in coffee agroecosystems facilitates movement for $A$. sericeasur and potentially increases ant recruitment rates. Studies in natural systems have reported increases in ant activity with arboreal connections across the arboreal stratum (Yanoviak, 2015), possibly driven by the easy access these pathways provide to resources (Clay et al., 2010). Other ants, such as Pogonomyrmex spp., prefer linear arboreal substrates and switch to cleared routes as a mechanism to reduce the energetic costs of ant foraging (Fewell 
1988), and in some cases to decrease the risk of encountering predators (Catling, 1997; Yanoviak et al. 2011).

The observed increase in ant activity on connected coffee plants after the placement of strings suggests that structural connectivity can increase ant recruitment rates to foraging areas in coffee and may enhance the efficiency of movement for A. sericeasur. This may lead to increased foraging efficiency for ants and enhanced resource capture rates on coffee. However, this could also reflect other benefits associated with using linear arboreal substrates, such as avoiding predators, a behavior that is known to occur in A. sericeasur (Philpott, Perfecto, Vandermeer, \& Uno, 2009). Using more efficient foraging pathways and thereby avoiding the leaf litter as a primary foraging substrate may potentially protect $A$. sericeasur workers from the attack of the phorid fly parasitoid Pseudacteon spp. (Philpott et al., 2009).

While ant activity only significantly increased after string placement on connected coffee plants, we also observed lesser increases in ant activity on control coffee plants and nest trees (Figure 3). This unexpected result could mean that strings, a novel element in the environment, acted as a form of habitat modification or disturbance, which increased overall ant activity in the local area. However, if our manipulation was the cause, we would have expected the ants to attack the jute strings (e.g., Risch, McClure, Vandermeer, \& Waltz, 1977), a behavior that we did not observe during the experiment. Experiments in tropical forests have shown that the long-term removal of lianas can influence ant richness on trees (Yanoviak \& Schnitzer, 2013), and therefore may possibly also affect overall ant abundance and activity when promoted. It is also possible that other factors could potentially explain this result in control plants, such as changes in local abiotic factors that we did not measure systematically in our experiment. Future research which expands on the temporal scope of this study may be useful in assessing the long-term effects of artificial connectivity in this system.

Ant activity after string placement was negatively affected by distance to the nesting tree (Figure 4). This result is consistent with previous studies suggesting that within $5 \mathrm{~mA}$. sericeasur dominance in the leaf litter decreases with distance to the nesting tree (Ennis, 2010; Philpott, Maldonado, Vandermeer, \& Perfecto, 2004). However, in our study, the effect of distance after string placement was significant only on control plants, but not on connected plants. This suggests that connections could buffer the negative effects that larger distances from the nesting tree pose to ant activity and potentially increase antprovided biological control services in these plants.

Connected coffee plants also had significantly higher CBB removal than control plants (Figure 5). Overall, greater ant activity on coffee plants was associated with higher CBB removal rates (Supporting Information Figure S1), suggesting that ant activity directly influenced CBB removal rates. However, while this effect was significant on control coffee plants, it was only marginally significant on connected plants. While we believe that these results support the hypothesis that connectivity enhances ant foraging and biocontrol services on coffee, the use of dead CBB in this experiment as a proxy to measure biocontrol may explain the only marginally significant effect of ant activity

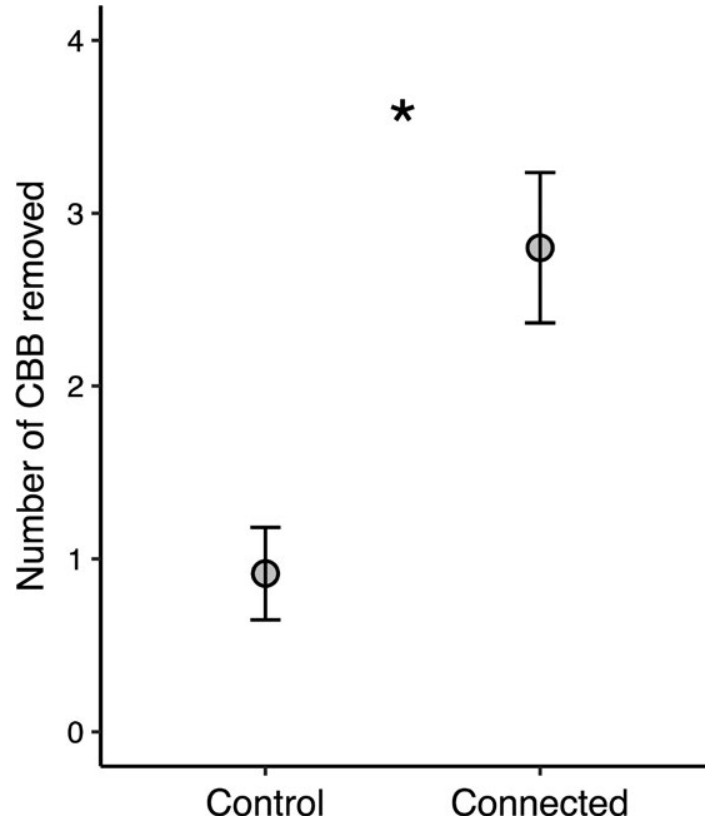

FIGURE 5 Coffee berry borer (CBB) removal in control and connected coffee plants after string placement. Bars = Mean $( \pm S E)$. The asterisk represents a statistically significant difference $(p<0.05)$

on CBB removal in connected plants. It is possible that dead prey exhibit more variable recruitment responses from ants than live prey. Despite this, it is likely that strings facilitated ant movement to coffee plants by providing a smooth, linear substrate and indirectly increased CBB removal (Clay et al., 2010). In other systems, the leaf-cutting ant Atta cephalotes uses fallen branches to rapidly move between areas and thereby quickly discover new food resources (Farji-Brener et al., 2007). Similarly, these resources allow scouts to return quickly to the colony, minimizing the time taken for information transfer and recruitment of other foraging workers (Farji-Brener et al., 2007). The role of trunk trails and fallen branches has received extensive attention in the leaf-cutting ant system; however, fewer studies have looked at the influence of connectivity resources on foraging behavior of predatory arboreal ants.

Surprisingly, CBB removal did not follow the same trend as ant activity with distance to the nesting tree. While control plants tended to have lower CBB removal rates than connected plants as distance to the tree increased, we did not find a significant effect of distance on CBB removal in either control or connected plant groups. Collectively, these results suggest that connections in the arboreal stratum have the potential to increase ant activity and therefore enhance plant protection from CBB attack, particularly in connected plants. Further studies should assess the effect of distance on CBB removal using plants located at distances larger than $3.5 \mathrm{~m}$ from the tree.

It is important to note that enhanced ant activity on coffee plants could lead to increases in the density of ant-tended hemipterans, such as the green coffee scale, which if severe enough could reduce the productivity of coffee plants. However, the green coffee scale is 
not a major pest in the region of study, in contrast to the economically significant coffee berry borer (Morris et al., 2018). Furthermore, a recent study evaluating the benefits associated with the indirect Azteca-Coffea mutualism found that the protective benefit ants provide to coffee plants is positively associated with high densities of the scale (Rivera-Salinas, Hajian-Forooshani, Jiménez-Soto, CruzRodríguez, \& Philpott, 2018). This suggests that the enhanced CBB control by ants outweighs the costs associated with scale damage. However, these interactions may be context-dependent and still need to be fully evaluated in the field to provide a holistic understanding of the impact of connectivity on scale density and coffee yield.

Other ant species could also benefit from the addition of connections between coffee plants and shade trees, such as $C$. basalis and $P$. simplex, which were observed using these connections during our study. The ant $P$. simplex has been previously reported as an important CBB biocontrol agent, acting in conjunction with other species of ants to effectively suppress CBB at various life stages (Morris et al., 2018; Philpott et al., 2008). Therefore, this technique could support Azteca ants as well as other ant species that play an important role in suppressing CBB populations.

Our results support the general hypothesis that connectivity, one measure of habitat complexity, can sustain important ecological processes in natural and managed ecosystems. In aquatic systems, more complex habitats with macrophytes allow for greater food capture and maintain higher levels of diversity (Crowder et al., 1998; Warfe \& Barmuta, 2004). In terrestrial systems, higher complexity can influence trophic dynamics (Polis \& Strong, 1996; Sanders, Nickel, Grützner, \& Platner, 2008). In coffee agroecosystems, ants are highly sensitive to habitat change and management intensification, generally expressed as the reduction of shade, elimination of epiphytes, and use of chemical inputs (Armbrecht, Rivera, \& Perfecto, 2005; Floren \& Linsenmair, 2005; Philpott et al., 2008; Roth, Perfecto, \& Rathcke, 1994). Such intensification can have a negative effect not only on vegetation connectivity and ant foraging, but may also cascade to affect ecosystem services, such as biological control. Our study supports the idea that promoting complexity at a local scale, in this case providing structural resources for ants in agroecosystems, can significantly enhance connectivity within the arboreal strata, and potentially improve biological control of coffee pests. This idea has already been successfully implemented in other agricultural systems, placing "ant bridges" made of bamboo strips or strings connecting neighboring trees in (Debach, 1964; Van Mele et al., 2009), and could be incorporated as a management strategy in coffee systems.

Future research should evaluate the practical feasibility of adding connections between vegetation strata to enhance biocontrol. For example, studies in timber plantations have estimated that the presence of ants increases timber production by $40 \%$, and that ants can be maintained at lower costs by providing intra-colony host tree connections using rope, poles or lianas (Offenberg, 2015). It is important that future studies in coffee also consider the costs of other CBB control methods, such as the application of the pesticide endosulfan, which can lead to the development of resistance, can negatively impact natural enemies, and can have harmful impacts on human health (Damon, 2001; Jaramillo, Borgemeister, \& Baker, 2006). Further investigation into promoting ant biocontrol with artificial connections in coffee should: (a) assess economic trade-offs, management applicability, and farmers' perceptions of this method in large and small coffee plantations, (b) compare the cost between string placement and other management approaches (e.g., pesticides, entomopathogens), and (c) assess coffee yields on connected and not connected plants to provide management recommendations.

More broadly, incorporating conservation biocontrol strategies in combination with vegetation connectivity is consistent with criteria identified as key for the sustainability of biological control, such as increasing local habitat quality and enhancing species' dispersal ability (Perfecto, Rice, Greenberg, \& Van der Voort, 1996; Tscharntke et al. 2005). Generally, the maintenance of shade trees and natural vegetation in agroforestry systems may increase vegetation complexity and natural connectivity between plants to promote ant foraging and subsequent biological pest control.

\section{ACKNOWLEDGMENTS}

We would like to thank the administrative and field personnel at Finca Irlanda for allowing us to carry out our research in their coffee plantation. We are grateful to $\mathrm{H}$. U. Vazquez Perez for providing field assistance during the experiment and to O. G. Lopez Bautista for providing logistical support during our study. We are especially thankful to Pranav Yajnik at U-M and Dr. Kai Zhu and Graeme Baird at UCSC for their insightful comments on our statistical analyses. We also thank Z. Hajian-Forooshani and D. Gonthier for providing figure graphics. This project was financed by the UC-MEXUS Dissertation Grant, a UCSC Heller Agroecology Graduate Student Research Grant, and CONACyT.

\section{DATA AVAILABILITY}

Data available from the Dryad Digital Repository: https://doi. org/10.5061/dryad.rk26g0n (Jimenez-Soto, Morris, Letourneau, \& Philpott, 2018).

\section{ORCID}

Estelí Jimenez-Soto (iD https://orcid.org/0000-0002-1150-2140

\section{REFERENCES}

Abdulla, N. R., Rwegasira, G. M., Jensen, K. M. V., Mwatawala, M. W., \& Offenberg, J. (2016). Control of mango seed weevils (Sternochetus mangiferae) using the African Weaver Ant (Oecophylla longinoda Latreille) (Hymenoptera: Formicidae). Journal of Applied Entomology, 140, 500-506. https://doi.org/10.1111/jen.12260

Adams, B. J., Schnitzer, S. A., \& Yanoviak, S. P. (2017). Trees as islands: Canopy ant species richness increases with the size of liana-free 
trees in a Neotropical forest. Ecography, 40, 1067-1075. https://doi. org/10.1111/ecog.02608

Andersen, A. N. (1986). Diversity, seasonality and community organization of ants at adjacent heath and woodland sites in southeastern Australia. Australian Journal of Zoology, 34, 53-64. https://doi. org/10.1071/ZO9860053

Apple, J., \& Feener, D. Jr (2001). Ant visitation of extrafloral nectaries of Passiflora: The effects of nectary attributes and ant behavior on patterns in facultative ant-plant mutualisms. Oecologia, 127, 409-416. https://doi.org/10.1007/s004420000605

Armbrecht, I., \& Gallego, M. C. (2007). Testing ant predation on the coffee berry borer in shaded and sun coffee plantations in Colombia. Entomologia Experimentalis et Applicata, 124, 261-267. https://doi. org/10.1111/j.1570-7458.2007.00574.x

Armbrecht, I., \& Perfecto, I. (2003). Litter-twig dwelling ant species richness and predation potential within a forest fragment and neighboring coffee plantations of contrasting habitat quality in Mexico. Agriculture, Ecosystems and Environment, 97, 107-115. https://doi. org/10.1016/S0167-8809(03)00128-2

Armbrecht, I., Rivera, L., \& Perfecto, I. (2005). Reduced diversity and complexity in the leaf-litter ant assemblage of colombian coffee plantations. Conservation Biology, 19, 897-907. https://doi. org/10.1111/j.1523-1739.2005.00062.x

Arroyo-Rodríguez, V., Asensio, N., Dunn, J. C., Cristóbal-Azkarate, J., \& Gonzalez-Zamora, A. (2015). Use of lianas by primates: More than a food source. In S. A. Schnitzer, F. Bongers, R. Burnham, \& F. E. Putz (Eds.), Ecology of lianas (pp. 407-426). Hoboken, NJ: John Wiley \& Sons. https://doi.org/10.1007/978-3-540-30290-2

Barrera, J. F. (Ed.) (2002). La broca del cafe: Una plaga que llego para quedarse. In Tres plagas del cafe en Chiapas (pp. 17-20). Lerma Campeche, Mexico: El Colegio de la Frontera Sur.

Bates, D., Maechler, M., Bolker, B., \& Walker, S. (2014). Ime4: Linear mixed-effects models using Eigen and S4. $R$ package version 1.1-7. Retrieved from http://CRAN.R-project.org/package=Ime4

Bos, M. M., Höhn, P., Saleh, S., Büche, B., Buchori, D., Steffan-Dewenter I., \& Tscharntke, T. (2007). Insect diversity responses to forest conversion and agroforestry management. In T. Tscharntke, C. Leuschner, M. Zeller, E. Guhardja, \& A. Bidin (Eds.), Stability of tropical rainforest margins (pp. 277-294). Berlin, Germany: Springer.

Camargo, P. H., Martins, M. M., Feitosa, R. M., \& Christianini, A. V. (2016). Bird and ant synergy increases the seed dispersal effectiveness of an ornithochoric shrub. Oecologia, 181, 507-518. https://doi. org/10.1007/s00442-016-3571-z

Camilo, J. E., Olivares, F. F., \& Jimenez, H. A. (2003). Fenologia y reproduccion de la broca del café (Hypothenemus hampei Ferrari) durante el desarrollo del fruto. Agronomia Mesoamericana, 14, 1559-1563.

Catling, P. M. (1997). Influence of aerial Azteca nests on the epiphyte community of some Belizean orange orchards. Biotropica, 29, 237242. https://doi.org/10.1111/j.1744-7429.1997.tb00031.x

Clausen, C. P. (1940). Entomophagous insects. London, UK: McGraw Hill Book.

Clay, N. A., Bauer, M., Solis, M., \& Yanoviak, S. P. (2010). Arboreal substrates influence foraging in tropical ants. Ecological Entomology, 35, 417-423.

Cogni, R., Freitas, A. V., \& Oliveira, P. S. (2003). Interhabitat differences in ant activity on plant foliage: Ants at extrafloral nectaries of Hibiscus pernambucensis in sandy and mangrove forests. Entomologia Experimentalis et Applicata, 107, 125-131. https://doi. org/10.1046/j.1570-7458.2003.00046.x

Crowder, L. B., Mccollum, E. W., \& Martin, T. H. (1998). Changing perspectives on food web interactions in lake littoral zones. In E. Jeppesen, M. Sondergaard, M. Sondergaard, \& K. Christoffersen (Eds.), The structuring roles of submerged macrophytes in lakes (pp. 240-249). Berlin Heidelberg; New York, NY: Springer.
Damon, A. (2001). A review of the biology and control of the coffee berry borer, Hypothenemus hampei (Coleoptera: Scolytidae). Bulletin of Entomological Research, 90(6), 453-465.

Davidson, D. W., Cook, S. C., Snelling, R. R., \& Chua, T. H. (2003). Explaining the abundance of ants in lowland tropical rainforest canopies. Science, 300(5621), 969-972. https://doi.org/10.1126/ science.1082074

De La Mora, A., Murnen, C., \& Philpott, S. (2013). Local and landscape drivers of biodiversity of four groups of ants in coffee landscapes. Biodiversity and Conservation, 22, 871-888. https://doi.org/10.1007/ s10531-013-0454-z

De la Mora, A., Pérez-Lachaud, G., Lachaud, J.-P. \& Philpott, S. M. (2015). Local and landscape drivers of ant parasitism in a coffee landscape. Environmental entomology, 44, 939-950.

Debach, P. (1964). Biological control of insect pests and weeds. London, UK: Chapman and Hall.

Elston, D. A., Moss, R., Boulinier, T., Arrowsmith, C., \& Lambin, X. (2001). Analysis of aggregation, a worked example: Numbers of ticks on red grouse chicks. Parasitology, 122, 563-569.

Ennis, K. K. (2010). Ground-foraging ant diversity and the role of an aggressive ant (Azteca instabilis) in coffee agroecosystems. Master's Thesis. University of Michigan.

Fahrig, L. (2003). Effects of habitat fragmentation on biodiversity. Annual Review of Ecology Evolution and Systematics, 34, 487-515. https://doi. org/10.1146/annurev.ecolsys.34.011802.132419

Farji-Brener, A. G., Barrantes, G., Laverde, O., Fierro-Calderon, K., Bascope, F., \& Lopez, A. (2007). Fallen branches as part of leafcutting ant trails: Their role in resource discovery and leaf transport rates in Atta cephalotes. Biotropica, 39, 211-215.

Fewell, J. H. (1988). Energetic and time costs of foraging in harvester ants, Pogonomyrmex occidentalis. Behavioral Ecology and Sociobiology, 22, 401-408. https://doi.org/10.1007/BF00294977

Floren, A., Biun, A., \& Linsenmair, E. K. (2002). Arboreal ants as key predators in tropical lowland rainforest trees. Oecologia, 131, 137-144. https://doi.org/10.1007/s00442-002-0874-z

Floren, A., \& Linsenmair, K. E. (2005). The importance of primary tropical rain forest for species diversity: An investigation using arboreal ants as an example. Ecosystems, 8, 559-567. https://doi.org/10.1007/ s10021-002-0272-8

Gonthier, D. J., Ennis, K. K., Philpott, S. M., Vandermeer, J., \& Perfecto, I. (2013). Ants defend coffee from berry borer colonization. BioControl, 58, 815-820. https://doi.org/10.1007/s10526-013-9541-z

Gordon, D. M. (2012). The dynamics of foraging trails in the tropical arboreal ant Cephalotes goniodontus. PLoS One, 7, e50472. https://doi. org/10.1371/journal.pone.0050472

Halaj, J., Ross, D. W., \& Moldenke, A. R. (1998). Habitat structure and prey availability as predictors of the abundance and community organization of spiders in western Oregon forest canopies. Journal of Arachnology, 26, 203-220.

Hashimoto, Y., Morimoto, Y., Widodo, E. S., \& Mohamed, M. (2006). Vertical distribution pattern of ants in a Bornean tropical rainforest (Hymenoptera: Formicidae). Sociobiology, 47, 697-710.

Huang, H., \& Yang, P. (1987). The ancient cultured citrus ant. BioScience, 37, 665-671. https://doi.org/10.2307/1310713

Jaramillo, J., Borgemeister, C., \& Baker, P. (2006). Coffee berry borer Hypothenemus hampei (Coleoptera: Curculionidae): Searching for sustainable control strategies. Bulletin of Entomological Research, 96, 223-233. https://doi.org/10.1079/BER2006434

Jedlicka, J. A., Greenberg, R., \& Letourneau, D. K. (2011). Avian conservation practices strengthen ecosystem services in California vineyards. PLoS One, 6, e27347. https://doi.org/10.1371/journal.pone.0027347

Jiménez-Soto, E., Cruz-Rodríguez, J. A., Vandermeer, J., \& Perfecto, I. (2013). Hypothenemus hampei (Coleoptera: Curculionidae) and its interactions with Azteca instabilis and Pheidole synanthropica 
(Hymenoptera: Formicidae) in a shade coffee agroecosystem. Environmental Entomology, 42, 915-924. https://doi.org/10.1603/ EN12202

Jimenez-Soto, E., Morris, J. R., Letourneau, D. K., \& Philpott, S. M. (2018). Data from: Vegetation connectivity increases ant activity and potential for ant-provided biocontrol services in a tropical agroforest. Dryad Digital Repository. https://doi.org/10.5061/dryad. rk26g0n

Langellotto, G. A., \& Denno, R. F. (2004). Responses of invertebrate natural enemies to complex-structured habitats: A metaanalytical synthesis. Oecologia, 139, 1-10. https://doi.org/10.1007/ s00442-004-1497-3

Larsen, A., \& Philpott, S. M. (2010). twig-nesting ants: The hidden predators of the coffee berry borer in Chiapas, Mexico. Biotropica, 42, 342-347. https://doi.org/10.1111/j.1744-7429.2009.00603.x

Lassau, S. A., and Hochuli, D. F. (2004). Effects of habitat complexity on ant assemblages. Ecography, 27, 157-164.

Lassau, S. A., Hochuli, D. F., Cassis, G., \& Reid, C. A. (2005). Effects of habitat complexity on forest beetle diversity: Do functional groups respond consistently? Diversity and Distributions, 11, 73-82. https:// doi.org/10.1111/j.1366-9516.2005.00124.x

Leston, D. (1973). The ant mosaic-tropical tree crops and the limiting of pests and diseases. PANS Pest Articles and News Summaries, 19, 311341. https://doi.org/10.1080/09670877309412778

Liere, H. and Larsen, A. (2010). Cascading trait-mediation: disruption of a trait-mediated mutualism by parasite-induced behavioral modification. Oikos, 119, 1394-1400.

Longino, J. T. (2007). A taxonomic review of the genus Azteca (Hymenoptera: Formicidae) in Costa Rica and a global revision of the Aurita group. Longwood, FL: Magnolia Press.

Longino, J. T., Coddington, J., \& Colwell, R. K. (2002). The ant fauna of a tropical rain forest: Estimating species richness three different ways. Ecology, 83, 689-702. https://doi.org/10.1890/0012-9658(2002)08 3[0689:TAFOAT]2.0.CO;2

Mayo, A., \& Benabib, M. (2009). Testing central place foraging theory in the ant genus Pogonomyrmex: A review of the literature from 1977 through 2008. Retrieved from https://figshare.com/articles/

Moguel, P., \& Toledo, V. M. (1999). Biodiversity conservation in traditional coffee systems of Mexico. Conservation Biology, 13, 11-21. https://doi.org/10.1046/j.1523-1739.1999.97153.x

Morris, J. R., Jimenez-Soto, M. E., Philpott, S. M., \& Perfecto, I. (2018). Antmediated biological control of the coffee berry borer (Hypothenemus hampei Ferrari): Diversity, ecological complexity, and conservation biocontrol. Myrmecological News, 26, 1-17.

Morris, J. R., \& Perfecto, I. (2016). Testing the potential for ant predation of immature coffee berry borer (Hypothenemus hampei) life stages. Agriculture, Ecosystems and Environment, 233, 224-228. https://doi. org/10.1016/j.agee.2016.09.018

Morris, J. R., Vandermeer, J., \& Perfecto, I. (2015). A keystone ant species provides robust biological control of the coffee berry borer under varying pest densities. PLoS One, 10, e0142850. https://doi. org/10.1371/journal.pone.0142850

Nestel, D., \& Dickschen, F. (1990). The foraging kinetics of ground ant communities in different Mexican coffee agroecosystems. Oecologia 84, 58-63. https://doi.org/10.1007/BF00665595

Offenberg, J. (2015). Ants as tools in sustainable agriculture. Journal of Applied Ecology, 52, 1197-1205. https://doi. org/10.1111/1365-2664.12496

Ozaki, K., Takashima, S., \& Suko, O. (2000). Ant predation suppresses populations of the scale insect Aulacaspis marina in natural mangrove forests. Biotropica, 32, 764-768. https://doi.org/10.1646/0006-360 6(2000)032[0764:APSPOT]2.0.CO;2

Pak, D., Iverson, A. L., Ennis, K. K., Gonthier, D. J., \& Vandermeer, J. H. (2015). Parasitoid wasps benefit from shade tree size and landscape complexity in Mexican coffee agroecosystems. Agriculture,
Ecosystems and Environment, 206, 21-32. https://doi.org/10.1016/j. agee.2015.03.017

Peng, R., \& Christian, K. (2014). Weaver ant role in cashew orchards in Vietnam. Journal of Economic Entomology, 107, 1330-1338. https:// doi.org/10.1603/EC14039

Perfecto, I., Rice, R. A., Greenberg, R., \& Van der Voort, M. E. (1996). Shade coffee: A disappearing refuge for biodiversity. BioScience, 46, 598-608.

Perfecto, I., \& Vandermeer, J. (2006). The effect of an ant-hemipteran mutualism on the coffee berry borer (Hypothenemus hampei) in southern Mexico. Agriculture, Ecosystems and Environment, 117, 218221. https://doi.org/10.1016/j.agee.2006.04.007

Philpott, S. M., Arendt, W. J., Armbrecht, I., Bichier, P., Diestch, T. V., Gordon, C., ... Zolotoff, J. M. (2008). Biodiversity loss in Latin American coffee landscapes: Review of the evidence on ants, birds, and trees. Conservation Biology, 22, 1093-1105. https://doi. org/10.1111/j.1523-1739.2008.01029.x

Philpott, S. M., \& Armbrecht, I. (2006). Biodiversity in tropical agroforests and the ecological role of ants and ant diversity in predatory function. Ecological Entomology, 31, 369-377. https://doi.org/10.1111/ j.1365-2311.2006.00793.x

Philpott, S. M., Maldonado, J., Vandermeer, J., \& Perfecto, I. (2004). Taking trophic cascades up a level: Behaviorally-modified effects of phorid flies on ants and ant prey in coffee agroecosystems. Oikos, 105, 141-147. https://doi.org/10.1111/ j.0030-1299.2004.12889.x

Philpott, S. M., Perfecto, I., Vandermeer, J., \& Uno, S. (2009). Spatial scale and density dependence in a host parasitoid system: An arboreal ant, Azteca instabilis, and its Pseudacteon phorid parasitoid. Environmental Entomology, 38, 790-796. https://doi. org/10.1603/022.038.0331

Polis, G. A., \& Strong, D. R. (1996). Food web complexity and community dynamics. American Naturalist, 147, 813-846. https://doi. org/10.1086/285880

Powell, S., Costa, A. N., Lopes, C. T., and Vasconcelos, H. L. (2011). Canopy connectivity and the availability of diverse nesting resources affect species coexistence in arboreal ants. Journal of Animal Ecology, $80,352-360$.

R Core Team (2014). R: A language and environment for statistical computing. Vienna, Austria: R Foundation for Statistical Computing. Retrieved from http://www.R-project.org/; http://CRAN.R-project. org $/$ package $=$ Ime 4

Risch, S., McClure, M., Vandermeer, J., \& Waltz, S. (1977). Mutualism between three species of tropical Piper (Piperaceae) and their ant inhabitants. American Midland Naturalist, 98, 433-444.

Rivera-Salinas, I. S., Hajian-Forooshani, Z., Jiménez-Soto, E., CruzRodríguez, J. A., \& Philpott, S. M. (2018). High intermediary mutualist density provides consistent biological control in a tripartite mutualism. Biological Control, 118, 26-31. https://doi.org/10.1016/j. biocontrol.2017.12.002

Roth, D. S., Perfecto, I., \& Rathcke, B. (1994). The effects of management systems on ground-foraging ant diversity in Costa Rica. Ecological Applications, 4, 423-436. https://doi.org/10.2307/1941947

Sanders, D., Nickel, H., Grützner, T., \& Platner, C. (2008). Habitat structure mediates top-down effects of spiders and ants on herbivores. Basic and Applied Ecology, 9, 152-160. https://doi.org/10.1016/j. baae.2007.01.003

Tanaka, H. O., Yamane, S., \& Itioka, T. (2010). Within-tree distribution of nest sites and foraging areas of ants on canopy trees in a tropical rainforest in Borneo. Population Ecology, 52, 147. https://doi. org/10.1007/s10144-009-0172-2

Teodoro, A., Sousa-Souto, L., Klein, A.-M., \& Tscharntke, T. (2010). Seasonal contrasts in the response of coffee ants to agroforestry shade-tree management. Environmental Entomology, 39, 1744-1750. https://doi.org/10.1603/EN10092 
Torres-Contreras, H., \& Vasquez, R. (2004). A field experiment on the influence of load transportation and patch distance on the locomotion velocity of Dorymyrmex goetschi (Hymenoptera, Formicidae). Insectes Sociaux, 51, 265-270.

Tscharntke, T., Klein, A. M., Kruess, A., Steffan-Dewenter, I., \& Thies, C. (2005). Landscape perspectives on agricultural intensification and biodiversity-ecosystem service management. Ecology Letters, 8 , 857-874.

Urrutia-Escobar, M. X., \& Armbrecht, I. (2013). Effect of two agroecological management strategies on ant (Hymenoptera: Formicidae) diversity on coffee plantations in southwestern Colombia. Environmental Entomology, 42, 194-203. https://doi.org/10.1603/EN11084

Van Mele, P. V., Cuc, N. T. T., Seguni, Z., Camara, K., \& Offenberg, J. (2009). Multiple sources of local knowledge: A global review of ways to reduce nuisance from the beneficial weaver ant Oecophylla. International Journal of Agricultural Resources, Governance and Ecology, 8, 484-504. https://doi.org/10.1504/IJARGE.2009.032646

Van Mele, P., \& Vayssières, J.-F. (2007). Weaver ants help farmers to capture organic markets. Appropriate Technology, 34, 22.

Vandermeer, J., Perfecto, I., Nuñez, G. I., Phillpott, S., \& Ballinas, A. G. (2002). Ants (Azteca sp.) as potential biological control agents in shade coffee production in Chiapas, Mexico. Agroforestry Systems, 56, 271-276. https://doi.org/10.1023/A:1021328820123

Vandermeer, J., Perfecto, I., \& Philpott, S. (2010). Ecological complexity and pest control in organic coffee production: Uncovering an autonomous ecosystem service. BioScience, 60, 527-537. https://doi. org/10.1525/bio.2010.60.7.8

Verdeny-Vilalta, O., Aluja, M., \& Casas, J. (2015). Relative roles of resource stimulus and vegetation architecture on the paths of flies foraging for fruit. Oikos, 124, 337-346. https://doi.org/10.1111/ oik.01557

Warfe, D. M., \& Barmuta, L. A. (2004). Habitat structural complexity mediates the foraging success of multiple predator species. Oecologia, 141, 171-178. https://doi.org/10.1007/s00442-004-1644-x
Wells, K., Pfeiffer, M., Lakim, M. B., \& Linsenmair, K. E. (2004). Use of arboreal and terrestrial space by a small mammal community in a tropical rain forest in Borneo, Malaysia. Journal of Biogeography, 31, 641-652. https://doi.org/10.1046/j.1365-2699.2003. 01032.x

Yanoviak, S. P. (2015). Effects of lianas on canopy arthropod community structure. In S. A. Schnitzer, F. Bongers, R. J. Burnham, \& F. E. Putz (Eds.), Ecology of lianas (pp. 343-361). Oxford, UK: Wiley-Blackwell.

Yanoviak, S. P., \& Schnitzer, S. A. (2013). Functional roles of lianas for forest canopy animals. In M. Lowman, S. Devy, \& T. Ganesh (Eds.), Treetops at risk (pp. 209-214). New York, NY: Springer.

Yanoviak, S. P., Munk, Y., \& Dudley, R. (2011). Evolution and ecology of directed aerial descent in arboreal ants. Integrative and comparative biology:icr006.

Yanoviak, S. P., Silveri, C., Stark, A. Y., Van Stan, J. T., \& Levia, D. F. (2017). Surface roughness affects the running speed of tropical canopy ants. Biotropica, 49, 92-100. https://doi.org/10.1111/btp.12349

\section{SUPPORTING INFORMATION}

Additional supporting information may be found online in the Supporting Information section at the end of the article.

How to cite this article: Jimenez-Soto E, Morris JR, Letourneau DK, Philpott SM. Vegetation connectivity increases ant activity and potential for ant-provided biocontrol services in a tropical agroforest. Biotropica. 2019;51:50-61. https://doi.org/10.1111/btp.12616 